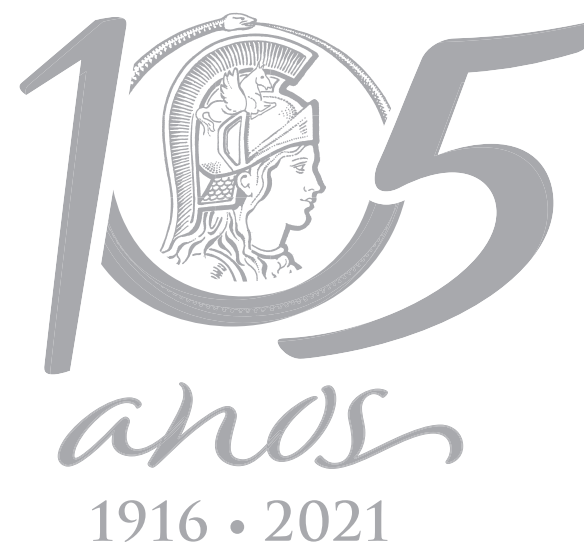

\title{
Influence of different Eucalyptus hybrids on soil macrofauna
}

\author{
VANESSA S. GOMES, PATRÍCIA A.B. BARRETO-GARCIA, RAFAEL N. SCORIZA, \\ VALDEMIRO C. JÚNIOR, JHULY E.S. PEREIRA \& JAMILY S. FERNANDES
}

\begin{abstract}
The present work aimed to evaluate the influence of different eucalyptus hybrids on the edaphic macrofauna community. It is hypothesized that the density and diversity of edaphic fauna are influenced by the quantity and quality of the litter deposited by the different hybrids on the soil surface. The study area is in the city of Vitória da Conquista (BA) and consists of seven eucalyptus hybrids, one from sexual reproduction (seminal) and six from asexual (clonal) reproduction. Sampling of the soil macrofauna was performed by the Tropical Soil Biology and Fertility method. All visible invertebrates were collected and identified at the level of large taxonomic groups. The relative density, group richness, and diversity index were calculated. Hybrids did not influence the total density and richness of the soil macrofauna. However, it was possible to observe changes in litter accumulation and composition, and as a result in the diversity indexes and in the presence or absence of macrofauna groups. Among the studied hybrids, those from Eucalyptus urophylla (seminal, 1335 and 1249) promote greater macrofauna diversity and favor the occurrence of detritivores organisms, suggesting the occurrence of better quality and more palatable litter for the edaphic fauna.
\end{abstract}

Key words: clones, invertebrates, litter, soil fauna.

\section{INTRODUCTION}

The growing demand for forest products has led to expanding the plantation area in Brazil, which already corresponded to approximately 7.8 million hectares in 2018. Of this total, about $73 \%$ correspond to the Eucalyptus genus (IBÁ 2019). These plantations gain even more importance in the Northeast of Brazil, where the vegetable energy demand represents about 30\% of the region's primary energy and has been predominantly supplied by exploiting native forest remnants (Fraga et al. 2014). In particular, the Eucalyptus areas in the Southwest of Bahia are in the process of expanding, with most of the plantations aimed at producing energy biomass (Oliveira et al. 2020) and coming from hybrids resulting from the genetic improvement of different species (Castro et al. 2016). Among the main reasons why the genus is one of the most widespread in Brazil is its ability to adapt and be used for various purposes such as in the production of oils and wood for coal, cellulose and paper and sawmills, in addition to several other products (IBÁ 2019).

The continuous deposition of senescent material from the shoot and root system in Eucalyptus plantations enables an accumulation of a thick layer of litter on the soil surface. In addition to representing a way of organic matter to enter and accumulate in the soil (Barbosa et al. 2017), the litter constitutes a habitat, protection and an energy source for abundant 
edaphic fauna composed by macro and micro invertebrates (Pinheiro et al. 2014).

Litter is a substantial part of the soil's food chain, and therefore any factor which changes its quantity and quality (such as plantation species composition and age) can directly influence the species richness and density of the edaphic macrofauna community (Riutta et al. 2012, Ashford et al. 2013, Moraes et al. 2013). This is because this community is made up of primary decomposers which provide for the initial fragmentation and continuity of disaggregation by other organisms, being of fundamental importance for nutrient cycling and maintaining ecosystem productivity (Kibblewhite et al. 2007). For this reason, the amount and quality of litter accumulated in the soil has a direct influence on the soil macrofauna (Riutta et al. 2012, Moraes et al. 2013), modifying their ecological interactions and conditioning their abundance, diversity, functional typology and distribution (Lindenmayer et al. 2008). Thus, eucalyptus species or hybrids, may influence the abundance and diversity of soil fauna in different ways according to their genetic characteristics and litter accumulation potential.

Soil macroinvertebrates have a body size greater than $2 \mathrm{~mm}$ and are represented by more than 20 taxonomic groups, including earthworms (Oligochaeta), ants (Hymenoptera), diplopods (Diplopoda), beetles (Coleoptera) and spiders (Aranae) (Vasconcellos et al. 2013). In addition to their role in decomposition, these organisms are also responsible for several ecological functions in edaphic environments such as constructing macropores, transporting soil materials and incorporating organic matter (Melo et al. 2009).

Although research has already been conducted to evaluate the soil fauna community in eucalyptus plantations in Brazil (Moço et al. 2005, Camara et al. 2012, Maestri et al. 2013, Garlet et al. 2015, Tacca et al. 2017, Neto et al. 2018), there are still few studies which consider the relationship of edaphic fauna with the presence of different Eucalyptus species or hybrids (Garlet et al. 2013), especially in regions where rainfall distribution and quantity are factors limiting productivity. In this context, this work aimed to evaluate the influence of different Eucalyptus hybrids on the edaphic macrofauna community. It is hypothesized that the density and diversity of edaphic fauna are influenced by the quantity and quality of the litter deposited by the different hybrids on the soil surface.

\section{MATERIALS AND METHODS}

\section{Characterization of the study area}

The study was conducted at Baixão farm (geographical coordinates: $14^{\circ} 49^{\prime} \mathrm{S}$ and $40^{\circ}$ $59^{\prime} \mathrm{W}$ ), located in Pradoso district, belonging to the municipality of Vitória da Conquista, Bahia, Brazil. The region has a flat to gently undulating topography and tropical altitude climate (Cwb) according to the Köppen classification, with an annual average temperature of $21^{\circ} \mathrm{C}$, annual rainfall of approximately $700 \mathrm{~mm}$ and an altitude ranging from 857 to $1,000 \mathrm{~m}$. The soil belongs to the Dystrophic Yellow Latosol class, having a clayey texture and low natural fertility (Table I).

\section{Treatments and experimental design}

The study area is approximately two hectares and is composed of seven eucalyptus hybrids, one from sexual reproduction (seminal) and six from asexual reproduction (clonal): seminal Eucalyptus urophylla, clone 1144 - Eucalyptus urophylla, clone $1355-$ E. urophylla $\times$ E. grandis, clone 1404 - Eucalyptus urophylla, clone 1296 E. urophylla $\times$ E. grandis, clone 1249 - E. urophylla $x$ E. grandis, and clone VM058 - E. grandis X E. camaldulensis, all four years old and having dendrometric characteristics according to Table II. The planting was established from seedlings, 
Table I. Chemical and granulometric characterization of soil at depth $0-20 \mathrm{~cm}$.

\begin{tabular}{|c|c|c|c|c|c|c|c|c|c|c|c|c|c|c|c|}
\hline $\mathbf{p H}$ & $\mathbf{P}$ & $\mathbf{K}$ & $\mathbf{C a}$ & $\mathbf{M g}$ & $\mathbf{A l}$ & $\mathbf{H + A l}$ & $\mathbf{N a}$ & $\mathbf{S B}$ & $\mathbf{t}$ & $\mathbf{T}$ & $\mathbf{V}$ & $\mathbf{m}$ & Sand & Silt & Clay \\
\hline & $\mathbf{m g ~ d m}^{-\mathbf{3}}$ & \multicolumn{8}{|c|}{$-----\mathbf{~ c m o l c ~ d m}^{-3}-------$} \\
\hline 4.4 & 2.0 & 0.13 & 0.6 & 0.5 & 1.2 & 6.0 & 0.00 & 1.2 & 2.4 & 7.2 & 17 & 49 & 630 & 20 & 350 \\
\hline
\end{tabular}

Analyses performed according to EMBRAPA (2017): $\mathrm{pH}$ (water); Mehlich ${ }^{-1}$ extractable $\mathrm{P}$ and $\mathrm{K} ; \mathrm{Ca}, \mathrm{Mg}$ and Al exchangeable for $1 \mathrm{~mol} \mathrm{~L}^{-1} \mathrm{KCl}$. Where: $\mathrm{H}+$ Al: potential acidity; $\mathrm{SB}=$ sum of bases; $\mathrm{t}$ = effective cation exchange capacity; $\mathrm{T}$ = cation exchange capacity at $\mathrm{ph} 7 ; \mathrm{V}=$ base saturation; $\mathrm{m}=$ aluminum saturation. We used samples composed of 10 simple samples collected in the experimental area.

adopting $3 \times 4 \mathrm{~m}$ spacing and randomized block design (RBC), with seven treatments and three replications, totaling 21 plots. Each experimental plot consisted of 3 plant lines containing 17 individuals each, with the 3 central plants of the intermediate line being considered as the useful plot.

The soil moisture and accumulated litter associated with eucalyptus hybrids at the soil collection moments were according to Table III. The area consisted of degraded pasture prior to the experiment installation. The tillage was done by plowing, subsoiling the planting lines (50 cm deep) and fertilization located in the pit (300 grams of Basifós Forest 2 commercial fertilizer, which contained: $\mathrm{N}, \mathrm{P}_{2} \mathrm{O}_{5}, \mathrm{~K}_{2} \mathrm{O}, \mathrm{Ca}, \mathrm{S}, \mathrm{Mg}$, $\mathrm{Zn}, \mathrm{Mn}, \mathrm{Cu}$ and B).

\section{Evaluation of edaphic fauna}

The soil collections for fauna capture were carried out in December 2017. Each useful plot tree constituted a collection point, totaling 3 sampling points per plot, with the obtained data being used to obtain an average of each plot. In total, 9 points per treatment and 63 points in every experiment were sampled. The macrofauna was sampled by the method recommended by Tropical Soil Biology and Fertility (TSBF) (Anderson \& Ingram 1993) with depth adaptation. Thus, soil monoliths $25 \times 25$ $\mathrm{cm}$ wide and $10 \mathrm{~cm}$ deep were collected, one meter away from the trunk of each sample tree. After removal of the monolith, manual sorting was carried out with the aid of a tray and tweezers. The organisms were visible to the naked eye, collected and packed in plastic bottles containing 70\% alcohol solution. Invertebrates were subsequently counted and identified at the level of large taxonomic groups according to Ruggiero et al. (2015).

The number of individuals for each group and the total number of individuals per eucalyptus hybrid was estimated by extrapolating the mean value for number of individuals per $\mathrm{m}^{2}$. The relative distribution (\%) was calculated by the total ratio of individuals in each group/ total of individuals. Total richness (number of identified groups), mean richness, and Shannon $\left(H^{\prime}=-\Sigma\right.$ pi log pi) and Pielou's evenness $\left(J^{\prime}=H^{\prime}\right.$ $\log R^{-1}$ ) indices were also obtained, where $\mathrm{pi}$ is the relative frequency of individuals from each taxonomic group and $\mathrm{R}$ is the richness defined as the number of different taxonomic units collected in each evaluated treatment (Odum \& Barrett 2011).

\section{Statistical analysis}

Data were tested for homogeneity (Cochran and Barttlet test, 5\%) and normality (Lilliefors test, $5 \%$ ). The Friedman test at $5 \%$ probability was adopted to verify differences between treatments after verifying the non-normality and homogeneity of the data. Principal component analysis (PCA) of the soil macrofauna community and abiotic factors (leaves, bark, branches, DBH, height and soil moisture) were complementarily performed with the aid of Canoco ${ }^{\circledR} \mathrm{V} .4 .5$ software (Lepš \& Šmilauer 2003). In addition, Pearson correlation analyses were performed between biotic and abiotic factors. 
Table II. Dendrometric characteristics of seven 4-year-old Eucalyptus hybrids in Vitória da Conquista - BA.

\begin{tabular}{|c|c|c|c|c|c|c|c|}
\hline \multirow{2}{*}{ Dendrometric variable } & \multicolumn{7}{|c|}{ Hybrids } \\
\cline { 2 - 8 } & Seminal & $\mathbf{1 1 4 4}$ & $\mathbf{1 3 5 5}$ & $\mathbf{1 4 0 4}$ & $\mathbf{1 2 9 6}$ & $\mathbf{1 2 4 9}$ & VM058 \\
\hline DBH (cm) & 13.3 & 14.0 & 15.9 & 13.2 & 16.0 & 14.0 & 15.4 \\
\hline H $(m)$ & 15.0 & 16.3 & 16.5 & 15.8 & 18.8 & 15.3 & 17.8 \\
\hline
\end{tabular}

In which: DBH $(\mathrm{cm})=$ diameter at breast height in centimeters; $\mathrm{H}=$ height in meters; Seminal = Eucalyptus urophylla; I144 = $E$. urophylla; $1355=$ E. urophylla $\times$ E. grandis; $1404=$ E. urophylla; $1296=$ E. urophylla $\times$ E. grandis; $1249=$ E. urophylla $\times$ E. grandis; $\mathrm{VM} 058=$ E. grandis $\mathrm{x}$. camaldulensis.

Table III. Accumulated litter and soil moisture associated with different four-year-old Eucalyptus hybrids in Vitória da Conquista - BA.

\begin{tabular}{|c|c|c|c|c|c|}
\hline \multirow{2}{*}{ Hybrid } & \multicolumn{4}{|c|}{ Litter (Mg ha ${ }^{-1}$ ) } & \multirow{2}{*}{ Soil moisture (\%) } \\
\hline & Leaves & Bark & Branches & Total & \\
\hline Seminal & 6.51 & 0.24 & 2.37 & 9.12 & 11.03 \\
\hline 144 & 6.02 & 0.09 & 1.86 & 7.98 & 11.06 \\
\hline 1355 & 6.02 & 0.03 & 1.48 & 7.52 & 11.16 \\
\hline 1404 & 5.99 & 0.35 & 4.32 & 10.66 & 12.84 \\
\hline 1296 & 7.17 & 0.18 & 1.29 & 8.64 & 11.58 \\
\hline 1249 & 5.60 & 0.16 & 1.55 & 7.31 & 13.21 \\
\hline VM058 & 10.59 & 0.08 & 3.55 & 14.23 & 13.21 \\
\hline
\end{tabular}

In which: Litter = dry mass of accumulated soil phytomass, obtained from collection in an area of $1.0 \mathrm{~m}^{2}(1.0 \mathrm{~m} \times 1.0 \mathrm{~m})$ around the trunk of each sample tree. Soil moisture $=$ Current soil moisture at depth $0-10 \mathrm{~cm}$, determined from soil samples $(0-10 \mathrm{~cm}$ depth) at the same collection points of the edaphic macrofauna. Seminal = Eucalyptus urophylla; $1144=E$. urophylla; $1355=E$. urophylla $\times$ E. grandis; $1404=$ E. urophylla; $1296=$ E. urophylla $\times$ E. grandis; $1249=$ E. urophylla $\times$ E. grandis; VM058 = E. grandis $\times$ E. camaldulensis.

\section{RESULTS AND DISCUSSION}

Considering the set of hybrids studied, 1,237 individuals were found, distributed in 14 taxonomic levels (Table IV). The total density of individuals varied between 49.8 individuals $\mathrm{m}^{-2}$ (clone 1249) and 337.8 individuals $\mathrm{m}^{-2}$ (clone 1296), but there were no significant differences between hybrids. The high density observed for clone 1296 (337.8 ind $\mathrm{m}^{-2}$ ) was influenced by the expressive density of the Isoptera group, which represented $92 \%$ of the total groups found. These results are corroborated by those of Moço et al. (2005) in studying soil macrofauna under eucalyptus and adopting the same methodology. These authors observed average density values of 262 individuals $\mathrm{m}^{-2}$ (in summer) and 496 individuals $\mathrm{m}^{-2}$ (in winter), with an expressive participation of the Isoptera group, which represented $32 \%$ of the abundance. Several factors control the density of edaphic macrofauna (highlighting the type of vegetation cover among the most representative) which determines the chemical composition of litter, as well as environmental conditions such as temperature, humidity/moisture and soil characteristics of the site (Decaëns 2010).

The results of total and average macrofauna richness did not show differences between the studied hybrids. However, it was possible to notice less expressive Shannon diversity $\left(H^{\prime}\right)$ and Pielou ( $\left.J^{\prime}\right)$ evenness indices in clones 1144 and 1296 (Table IV), which may be related to 
Table IV. Relative density (\%) of the large taxonomic groups, standard deviation (in parentheses), density, standard error, total and average richness, and Shannon and Pielou indices of the soil macrofauna under Eucalyptus hybrids in Vitória da Conquista, Bahia.

\begin{tabular}{|c|c|c|c|c|c|c|c|}
\hline \multirow{2}{*}{ Groups } & \multicolumn{7}{|c|}{ Hybrid } \\
\hline & Seminal & I144 & 1335 & 1404 & 1296 & 1249 & VM058 \\
\hline Araneae & 0.0 & $0.6(0.6)$ & 0.0 & $0.9(1.3)$ & $1.1(1.1)$ & 0.0 & $2.7(3.0)$ \\
\hline Blattodea & 0.0 & $0.6(0.6)$ & $1.5(2.3)$ & 0.0 & $1.1(1.1)$ & 0.0 & 0.0 \\
\hline Coleoptera & 0.0 & 0.0 & 0.0 & 0.0 & $1.1(0.7)$ & $7.1(10.4)$ & $2.7(3.0)$ \\
\hline Diptera & $1.8(5.4)$ & 0.0 & 0.0 & $0.9(1.3)$ & 0.0 & 0.0 & 0.0 \\
\hline Formicidae & $14.3(17.2)$ & $10.0(5.3)$ & $19.7(13.7)$ & $21.4(26.1)$ & $2.1(1.2)$ & $28.6(36.4)$ & $6.8(4.9)$ \\
\hline Heteroptera & 0.0 & 0.0 & 0.0 & $0.9(1.3)$ & 0.0 & 0.0 & $1.4(2.3)$ \\
\hline Hymenoptera & 0.0 & 0.0 & 0.0 & 0.0 & 0.0 & 0.0 & $1.4(2.3)$ \\
\hline Isopoda & $1.8(5.4)$ & 0.0 & $7.6(6.0)$ & 0.0 & $1.1(0.7)$ & 0.0 & 0.0 \\
\hline Isoptera & $23.2(70.6)$ & $87.6(96.5)$ & $60.6(88.4)$ & $68.8(97.8)$ & $92.1(99.1)$ & 0.0 & $81.1(101.3)$ \\
\hline Coleoptera Larvae & $5.4(8.1)$ & 0.0 & $3.0(3.0)$ & $0.9(1.3)$ & $0.5(0.6)$ & 0.0 & 0.0 \\
\hline Diptera Larvae & 0.0 & 0.0 & 0.0 & 0.0 & 0.0 & $7.1(15.8)$ & 0.0 \\
\hline Formicidae Larvae & 0.0 & 0.0 & 0.0 & $6.3(9.3)$ & 0.0 & 0.0 & 0.0 \\
\hline Oligochaeta & $53.6(72.4)$ & $0.6(0.6)$ & $7.6(6.0)$ & 0.0 & $1.1(1.1)$ & $53.6(94.6)$ & $4.1(4.8)$ \\
\hline Psocoptera & 0.0 & $0.6(0.6)$ & 0.0 & 0.0 & 0.0 & $3.6(7.9)$ & 0.0 \\
\hline Mean density (ind $\mathrm{m}^{-2}$ ) & 99.6 & 302.2 & 117.3 & 199.1 & 337.8 & 49.8 & 131.6 \\
\hline Total standard error & 2.05 & 17.16 & 4.89 & 8.37 & 19.62 & 1.41 & 4.93 \\
\hline Total richness & 6 & 6 & 6 & 7 & 8 & 5 & 7 \\
\hline Mean richness & 1.67 & 1.11 & 1.67 & 1.33 & 1.33 & 1.00 & 1.56 \\
\hline$H^{\prime}$ & 1.81 & 0.67 & 1.71 & 1.34 & 0.61 & 1.71 & 1.14 \\
\hline$J^{\prime}$ & 0.70 & 0.26 & 0.66 & 0.48 & 0.20 & 0.74 & 0.41 \\
\hline
\end{tabular}

In which: Seminal = Eucalyptus urophylla; $1144=$ E. urophylla; $1355=$ E. urophylla x E. grandis; $1404=$ E. urophylla; $1296=E$. urophylla $\times$ E. grandis; $1249=$ E. urophylla $\times$ E. grandis; VM058 = E. grandis X E. camaldulensis; Total standard error - calculated based on the set of taxonomic groups for each hybrid, with $n=42$ (number of groups $x$ number of repetitions); $H^{\prime}=$ Shannon index; $J^{\prime}$ = Pielou evenness index.

the high predominance of Isoptera taxon to the detriment of other groups. This indicates that a larger number of individuals did not necessarily imply increased diversity associated with these hybrids. According to Walker (1989), the higher the density of fauna in a given vegetation cover, the greater the chance of some group being predominant and thus reducing the evenness.

In turn, more expressive $\mathrm{H}^{\prime}$ and J' values were found in the soil under seminal Eucalyptus urophylla and under clones 1335 and 1249 (Table IV), which shows that these hybrids favored better distribution of macrofauna individuals within groups without predominance of one group over another. According to Menezes et al. (2009), the Pielou index represents the uniform distribution of the number of individuals in the different groups.

The dominant groups were Oligochaeta, which represented $54 \%$ of the total number of individuals in the seminal eucalyptus and in the 1249 hybrid; and Isoptera, which represented more than $60 \%$ in the $1144,1335,1404,1296$ and VM058 hybrids. These groups showed a strong negative correlation with each other $(r=-0.85$; $p<0.05)$, meaning that the treatments which 
showed higher density in one group showed lower density in the other (Table IV). This suggests an environment effect on the occurrence of groups, especially since these Oligochaeta and Isoptera organisms are saprophages, and are therefore characterized by feeding directly on plant residues, fragmenting them (Moço et al. 2005).

The dominance of Oligochaeta is usually related to a better humidity condition, however no significant variations in soil moisture content were observed at the time of macrofauna assessment (Table III). According to Kernecker et al. (2015), the presence and survival of Oligochaeta is related to the vegetation characteristics and the amount of plant residues deposited, which regulate the humidity and the accumulation of organic matter in the soil (Cabrera 2012, Martins et al. 2017). Thus, it is possible that the dominance of earthworms in seminal and eucalyptus hybrid 1249 is related to differences in the deposited litter quality, which cause changes in the soil organic matter dynamics. Such differences can also explain the greater abundance of Isopteras in most of the studied hybrids, since these organisms typically feed on plant residues (wood, leaves and bark) accumulated on the soil surface (Jouquet et al. 2011), and can be influenced chemical composition.

According to Silva et al. (2014), the quality of litter is determined by its organic and inorganic composition (soluble fractions, nutrients, lignin, cellulose, phenolic compounds, carbon, stimulating or allelopathic substances), which has a great influence on the regulation and nature of saprophytic fauna interactions (Beare et al. 1992). For example, high levels of lignin and aromatic compounds give the material high resistance, making it difficult for soil organisms to penetrate.
The most abundant group among the studied treatments after Oligochaeta and Isoptera was Formicidae. Together, these three groups represented about $91 \%$ of all sampled edaphic macrofauna. The dominance of the Formicidae and Isoptera groups in eucalyptus monocultures was also reported by Silva et al. (2013), and is probably related to the fact that homogeneous forest systems provide a single food substrate. This favors the occurrence of faunistic groups with greater colonization capacity (Garlet et al. 2013) and a variety of eating habits (Santos et al. 2015) such as social insects. In this sense, Oligochaeta also has the capacity to adapt to local conditions, as it tends to take refuge in deeper layers of the soil and in more humid and shaded places during periods of water restriction.

The presence or absence of some fauna groups in the different hybrids suggests that the abundance and/or quality of the accumulated litter conditioned by the habitat characteristics, providing specific soil conditions. This would be regulating the occurrence of fauna groups, highlighting the Isoptera and Oligochaeta groups, which were absent in clones 1249 and 1404, respectively, and the Diptera, Heteroptera, Hymenoptera and Pscoptera groups, which occurred only in one or two of the seven studied hybrids (Diptera: seminal Eucalyptus and clone 1404; Heteroptera: clones 1404 and VM058; Hymenoptera: clone VM058; and Psocoptera: clones 1144 and 1249). According to Baretta et al. (2008), habitat characteristics such as climate, accumulated litter and organic matter content determine which fauna groups will be present in the soil and their amounts.

The principal component analysis (PCA), which considered the joint variation of the soil macrofauna community and abiotic factors (Figure 1), resulted in eigenvalues of $28.2 \%$ for the first axis and $24.2 \%$ for the second axis, which 


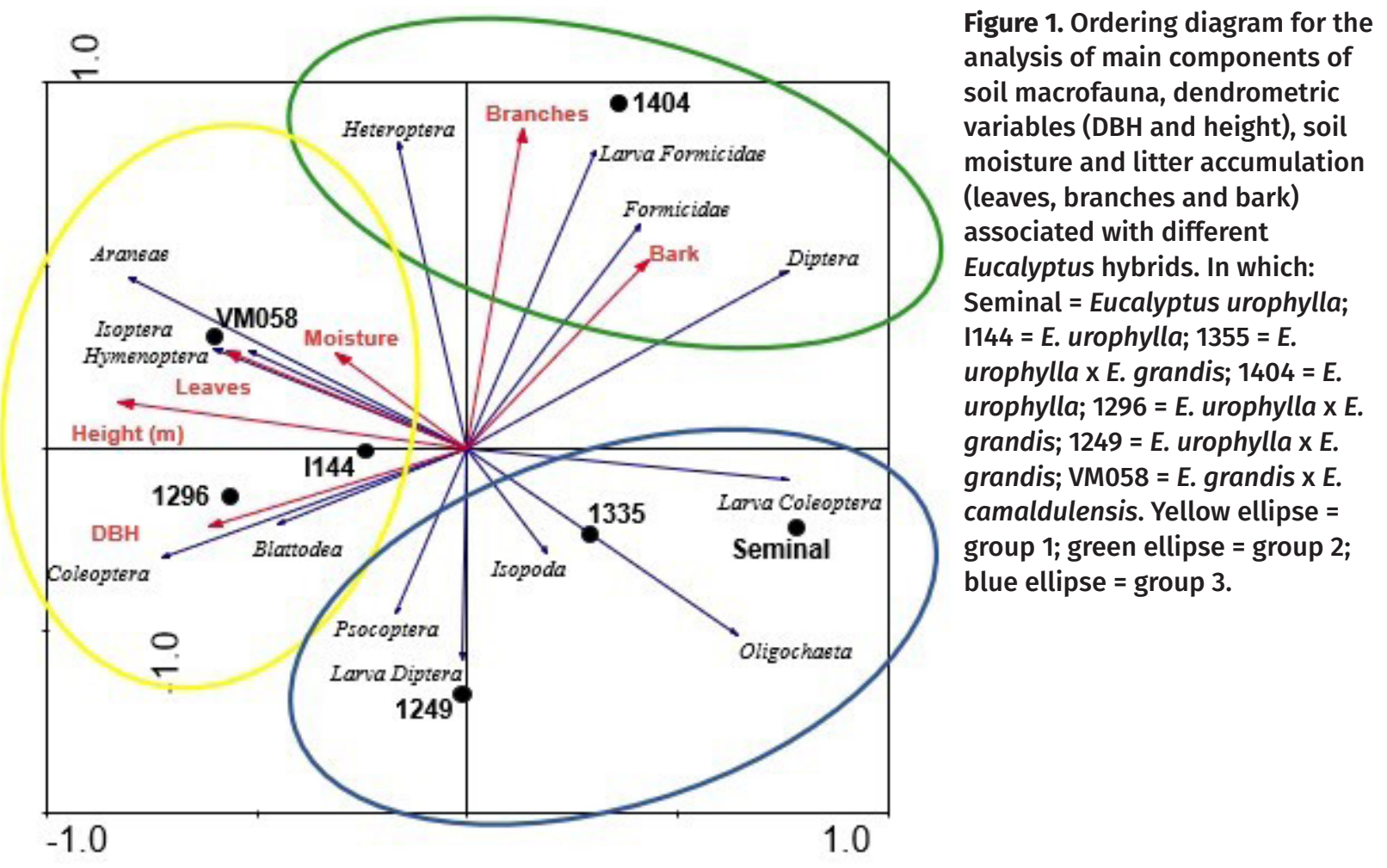

corresponds to $52.4 \%$ of the total cumulative variance in the first two axes. The graphic dispersion of the treatments in relation to the axes showed the formation of three groups: the first composed by the VM058, 1144 and 1296 hybrids, which were positioned to the left of the graph; the second was only composed by the 1404 hybrid which was isolated in the upper right quadrant; and the third was composed by the 1249, 1335 and seminal hybrids, positioned in the lower right part of the graph.

The variables most strongly associated with hybrids of the first group (VM058, I144 and 1296) were moisture, leaf litter, tree height, DBH and the Araneae, Blattodea, Coleoptera, Hymenoptera and Isoptera groups (Figure 1), which in general preferentially live in litter and in humid environments. This indicates that the influence of these hybrids on edaphic macrofauna is a consequence of factors such as tree size and their plant residue accumulation dynamics which conditions variations in soil moisture and temperature. Corroborating this information, the 1296 treatment showed more expressive height and DBH values (Table II), while the 1404 and VM058 treatments presented higher leaf litter and total litter accumulation (Table III). In addition, significant correlations of the Blattodea group with DBH $(r=0.78$; $p<0.05)$ and tree height ( $r=0.66 ; p<0.05)$, of the Araneae group with height $(r=0.76 ; p<0.05)$ and leaf litter $(r=0.66 ; p<0.05)$, and the Coleoptera group with soil moisture $(r=0.72 ; p<0.05)$. These results characterize the close relationship between plant, litter, soil and macrofauna, and are corroborated by the results of D.L. Machado (unpublished data) in different forest restoration systems, which found significant positive relationships between fauna groups (such as Coleoptera and Formicidae) and litter and vegetation attributes (basal area and density); by Pompeo et al. (2016) in planting pine and native forest, who observed a positive association between the Coleoptera group and soil moisture; and by Farias et al. 
(2015) in different land use systems, who found a positive relationship of Coleoptera species with moisture and other soil characteristics.

In turn, the most important variables for differentiating the 1404 hybrid were the bark and the branches of the litter, the Heteroptera, Formicidae, Diptera groups and the Formicidae larvae. Thus, the dissimilarity of this hybrid can be attributed to its larger accumulations of bark and branches in the litter (Table III), which favored the occurrence of groups, which use the litter as shelter, breeding sites or to take refuge. In line with this explanation, significant correlations were found between the litter bark component and the Diptera group $(r=$ 0.79; $p<0.05$ ), and between the branches and the Heteroptera group $(r=0.79 ; p<0.05)$. Bark serves as shelter for the Diptera order (Souza et al. 2007), while branch litter influence ant nests (Carvalho \& Vasconcelos 2002), as well as shelter for small ants (Freitas et al. 2003).

The third group, composed by the 1249 , 1335 and seminal hybrids, was more related to the Psocoptera, Isopoda, and Oligochaeta orders and Diptera and Coleoptera larvae. The association of these faunal groups, which are generally detritivores, can be explained by the fact that the three hybrids of the group come from the same species (Eucalyptus urophylla), which would be conditioning the deposition of vegetation residue with similar chemical and organic composition. This result suggests the occurrence of a better quality litter in these treatments, which would be providing the availability of more attractive food resources to detritivores.

\section{CONCLUSIONS}

Although without influence on the total density and richness of soil macrofauna, eucalyptus hybrids cause changes in litter accumulation and composition, and as a result in the diversity indexes and in the presence/absence of macrofauna groups. Among the studied hybrids, those from Eucalyptus urophylla (seminal, 1335 and 1249) promote greater macrofauna diversity and favor the occurrence of detritivores organisms, suggesting the occurrence of a better quality and more palatable litter for the edaphic fauna.

\section{Acknowledgments}

To the Conselho Nacional de Desenvolvimento Científico e Tecnológico (CNPq) for the Scientific Initiation scholarship granted for the study.

\section{REFERENCES}

ANDERSON JM \& INGRAM JSI. 1993. Tropical soil biological and fertility: a handbook of methods, 2nd ed., Wallingford: CAB International, $171 \mathrm{p}$.

ASHFORD OS, FOSTER WA, TURNER BL, SAYER EJ, SUTCLIFFE L \& TANNER EVJ. 2013. Litter manipulation and the soil arthropod community in a lowland tropical rainforest. Soil Biol Biochem 62: 5-12. http://dx.doi.org/10.1016/j. soilbio.2013.03.001.

BARBOSA V, BARRETO-GARCIA P, GAMA-RODRIGUES EF \& PAULA AD. 2017. Biomass, Carbon and Nitrogen in the Accumulated Litter of Planted and Native Forests. Floram 24: e20150243.

BARETTA D, FERREIRA CS, SOUZA JP \& CARDOSO EJBN. 2008. Colêmbolos (Hexapoda: Collembola) como bioindicadores de qualidade do solo em áreas com Araucaria angustifolia. Rev Bras Cienc Solo 32: 2693-2699.

BEARE MH, PARMELEE RW, HENDRIX PF, GHENG W, COLEMAN DC \& CROSSLEY JR DA. 1992. Microbial and faunal interactions and effects on litter nitrogen and decomposition agroecosystems. Ecol Monogr 62(4): 569-591.

CABRERA G. 2012. Edaphic macrofauna as biological indicator of the conservation/disturbance status of soil. Results obtained in Cuba. Past y Forr 35(4): 349-364.

CAMARA R, CORREIA MEF \& VILLELA DM. 2012. Effects of eucalyptus plantations on soil arthropod communities in a brazilian atlantic forest conservation unit. Biosci J 28: 445-455. 
CARVALHO KS \& VASCONCELOS HL. 2002. Comunidade de formigas que nidificam em pequenos galhos da serrapilheira em floresta da Amazônia Central, Brasil. Rev Bras Entomol 46: 115-121.

CASTRO CADO, RESENDE RT, BHERING LL \& CRUZ CD. 2016. Brief history of Eucalyptus breeding in Brazil under perspective of biometric advances. Cienc Rural 46: 1585-1593.

DECAËNS T. 2010. Macroecological patterns in soil communities. Global Ecol Biogeogr 19: 287-302.

EMBRAPA - EMPRESA BRASILEIRA DE PESQUISA AGROPECUÁRIA. 2017. Manual de Métodos de Análise de Solo, $3^{a}$ ed., Brasília, DF, 573 p.

FARIAS PM, ARELLANO L, HERNÁNDEZ MIM \& ORTIZ SL. 2015. Response of the copro-necrophagous beetle (Coleoptera: Scarabaeinae) assemblage to a range of soil characteristics and livestock management in a tropical landscape. J Insect Conserv 19(5): 947-960.

FRAGA MP, BARRETO PAB \& PAULA A. 2014. Estimação de volume de Pterogyne nitens em plantio puro no sudoeste da Bahia. Pesq Florest Bras 34 (79): 207-215.

FREITAS AVL, FRANCINI RB \& BROWN JR KS. 2003. Insetos como indicadores ambientais. In: Cullen L, Rudran R \& Valladares-Padua C (Eds), Métodos de estudos em biologia da conservação e manejo da vida silvestre, Curitiba: UFPR e Fundação O Boticário de Proteção a Natureza, p. 125-146.

GARLET J, COSTA EC \& BOSCARDIN J. 2013. Caracterização da fauna edáfica em plantios de Eucalyptus spp. Cienc Florest 23: 337-344.

GARLET J, COSTA EC, BOSCARDIN J, MACHADO DN \& PEDRON L. 2015. Fauna de Coleoptera Edáfica em eucalipto sob diferentes sistemas de controle químico da Matocompetição. Floram 22: 239-248.

IBÁ - INDÚSTRIA BRASILEIRA DE ÁRVORES. 2019. Relatório Ibá 2019. São Paulo: IBÁ, 80 p.

JOUQUET P, TRAORÉ S, CHOOSAI C, HARTMANN C \& BIGNELL D. 2011. Influence of termites on ecosystem functioning. Ecosystem services provided by termites. Eur J Soil Biol 47(4): 215-222. https://doi.org/10.1016/j.ejsobi.2011.05.005.

KERNECKER M, WHALEN JK \& BRADLEY R. 2015. Agricultural management and flooding shape habitats for nonnative earthworms in southern Quebec, Canada. Appl Soil Ecol 96: 240-250.

KIBBLEWHITE MG, RITZ K \& SWIFT MJ. 2007. Soil health in agricultural systems. Phil Trans R Soc B 363: 685-701.

LEPŠ J \& ŠMILAUER P. 2003. Multivariate analysis of ecological data using Canoco. Cambridge: Cambridge University Press, 288 p. Acesso em: jan. 2019. Disponível em: http://assets.cambridge.org/052181/409X/ sample/052181409XWS.pdf.

LINDENMAYER DB ET AL. 2008. A checklist for ecological management of landscapes for conservation. Ecol Lett 11: 78-91.

MAESTRI R, LEITE MADS, SCHMITT LZ \& RESTELLO RM. 2013. Efeito de mata nativa e bosque de eucalipto sobre a riqueza de artrópodos na serrapilheira. Perspectiva 37: 31-40.

MARTINS LF, PEREIRA JM, TONELLI M \& BARETTA D. 2017. Composição da macrofauna do solo sob diferentes usos da terra (cana-de-açúcar, eucalipto e mata nativa) em Jacutinga (MG). Rev Agrogeoambiental 9(1): 11-22. http:// dx.doi.org/10.18406/2316-1817v9n12017913.

MELO FV, BROWN GG, CONSTANTINO R, LOUZADA JNC, LUIZÃO FJ, MORAIS JW \& ZANETTI RA. 2009. Importância da meso e macrofauna do solo na fertilidade e como biondicadores. B Inf SBCS 34: 38-43.

MENEZES CEG, CORREIA MEF, PEREIRA MG, BATISTA I, RODRIGUES KM, COUTO WH, ANJOS LHC \& OLIVEIRA IP. 2009. Macrofauna edáfica em estádios sucessionais de floresta estacional semidecidual e pastagem mista em Pinheiral (RJ). Rev Bras Cienc Solo 33: 1647-1656.

MOÇO MKDS, DA GAMA-RODRIGUES EF, DA GAMA-RODRIGUES AC \& CORREIA MEF. 2005. Caracterização da fauna edáfica em diferentes coberturas vegetais na região norte fluminense. Rev Bras Cienc Solo 29: 555-564.

MORAES LFD, ASSUMPÇÃO JM, PEREIRA TS \& LUCHIARI C. 2013. Manual técnico para a restauração de áreas degradadas no Estado do Rio de Janeiro. Rio de Janeiro: Jardim Botânico do Rio de Janeiro, 84 p.

NETO TDAC, CAMARA R, DOS ANJOS LHC, CORREIA MEF, PEREIRA MG \& JACCOUD CFS. 2018. Relação fauna do solo-paisagem em plantio de eucalipto em topossequência. Floresta 48: 213-224.

ODUM EP \& BARRETT GW. 2011. Fundamentos de ecologia. São Paulo: Cengage Learning, 612 p.

OLIVEIRA AM, BARRETO-GARCIA, ALVES BJR, CONCEIÇÃO JÚNIOR W \& GAMA-RODRIGUES EF. 2020. Efeito de rotações sucessivas de eucalipto na mineralização de nitrogênio e carbono do solo e suprimento de nitrogênio, no Sudoeste da Bahia, Brasil. Sci For 48(126): e3346.

PINHEIRO FJ, MARTINS CM, FIALHO JS, CORREIA EF \& CASCON P. 2014. Caracterização da macrofauna edáfica na interface solo-serapilheira em uma área de Caatinga do Nordeste brasileiro. Enci Bio 10: 2964-2974.

POMPEO PN, SANTOS MAB, BIASI JP, SIQUEIRA S, ROSA MG, BARETTA CRDM \& BARETTA D. 2016. Fauna e sua relação com atributos edáficos em Lages, Santa Catarina-Brasil. 
Sci Agrar 17(1): 42-51. http://dx.doi.org/10.5380/rsa. v17i1.46535.

RIUTTA T, SLADE EM, BEBBER DP, TAYLOR ME, MALHI Y, RIORDAN P, MACDONALD DW \& MORECROFT MD. 2012. Experimental evidence for the interacting effects of forest edge, moisture and soil macrofauna on leaf litter decomposition. Soil Biol Biochem 49: 124-131. http:// dx.doi.org/10.1016/j.soilbio.2012.02.028.

RUGGIERO MA, GORDON DP, ORRELL TM, BAILLY N, BOURGOIN T, BRUSCA RC, CAVALIER-SMITH T, GUIRY MD \& KIRK PM. 2015. A higher level classification of all living organisms. PLoS ONE 10: 119-248.

SANTOS JOP, PERES FILHO O, DE SOUZA MD \& DORVAL A. 2015. Preferência de Atta laevigata F. SMITH, 1858 (Hymenoptera: Formicidae) por diferentes espécies e híbridos de eucaliptos. Rev Agric 90: 42-53.

SILVA CF, MARTINS MA, DA SILVA EMR, PEREIRA MG \& CORREIA MEF. 2013. Influência do sistema de plantio sobre atributos dendrométricos e fauna edáfica, em área degradada pela extração de argila. Rev Bras Cienc Solo 37: 1742-1751.

SILVA HF, BARRETO-GARCIA PAB, SOUSA GTO, AZEVEDO GB, GAMA-RODRIGUES EF \& OLIVEIRA FGRB. 2014. Decomposição de serapilheira foliar em três sistemas florestais no Sudoeste da Bahia. Rev Bras Bioc 12(3): 164-172.

SOUZA CM, SOUZA VB, AMÂNCIO S, SALOMÃO C, TIZO-PEDROSO E \& AUGUSTO SC. 2007. Artrópodes associados à serapilheira e troncos de árvores suberosas em uma área de cerradão em Uberlândia, MG. In: Congresso de Ecologia, Anais VIII CEB, Caxambu, MG, p. 1-2.

TACCA D, KLEIN C \& PREUSS JF. 2017. Artropodofauna do solo em um bosque de eucalipto e um remanescente de mata nativa no sul do Brasil. Rev Thema 14: 249-261.

VASCONCELLOS RLF, SEGATA JC, BONFIM JÁ, BARETTA D \& CARDOSO EJBN. 2013. Soil macrofauna as an indicator of soil quality in an undisturbed riparian forest and recovering sites of different ages. Eur J Soil Biol 58: 105-112.

WALKER D. 1989. Diversity and stability. In: Cherrett JM (Ed), Ecological concepts, Oxford: Blackwell Scientific Public, p. 115-146.

\section{How to cite}

GOMES VS, BARRETO-GARCIA PAB, SCORIZA RN, JÚNIOR VC, PEREIRA JES \& FERNANDES JS. 2022. Influence of different Eucalyptus hybrids on soil macrofauna. An Acad Bras Cienc 94: e20200247. DOI 10.1590/00013765202220200247.

Manuscript received on February 20, 2020; accepted for publication on May 22, 2020

\section{VANESSA S. GOMES ${ }^{1}$}

https://orcid.org/0000-0003-2149-2211

\section{PATRÍCIA A.B. BARRETO-GARCIA ${ }^{2}$}

https://orcid.org/0000-0002-8559-2927

\section{RAFAEL N. SCORIZA ${ }^{2}$}

https://orcid.org/0000-0001-7361-4095

\section{VALDEMIRO C. JÚNIOR ${ }^{3}$}

https://orcid.org/0000-0002-3030-2275

\section{JHULY E.S. PEREIRA ${ }^{4}$}

https://orcid.org/0000-0001-9793-2696

\section{JAMILY S. FERNANDES ${ }^{5}$}

https://orcid.org/0000-0002-2707-4275

${ }^{1}$ Bracell Bahia Florestal, Rua Doutor José Tiago Correa, s/n, Alagoinhas Velha, 48030-480 Alagoinhas, BA, Brazil ${ }^{2}$ Universidade Estadual do Sudoeste da Bahia (UESB), Departamento de Engenharia Agrícola e Solos, Estrada do Bem Querer, Km 4, s/n, Caixa Postal 95, 45083-900 Vitória da Conquista, BA, Brazil

${ }^{3}$ Universidade Estadual do Sudoeste da Bahia (UESB), Departamento de Fitotecnia e Zootecnia, Estrada do Bem Querer, Km 4, s/n, Caixa Postal 95, 45083-900 Vitória da Conquista, BA, Brazil

${ }^{4}$ Veracel Celulose, Rodovia Fazenda Brasilândia BA-275, Km 24, s/n, 45820-000 Zona Rural, Eunápolis, BA, Brazil

${ }^{5}$ Universidade Estadual Paulista Júlio de Mesquita Filho (UNESP), Faculdade de Ciências Agronômicas de Botucatu (FCA), Rua Doutor José Barbosa de Barros, 1780, Jardim Paraíso, 18610-307 Botucatu, SP, Brazil

Correspondence to: Patrícia Anjos Bittencourt Barreto-Garcia E-mail: patriciabarreto@uesb.edu.br

\section{Author contributions}

VSG: data curation, formal analysis, investigation, methodology and writing - original draft; PABBG: conceptualization, formal analysis, methodology, supervision and writing - review \& editing; RNS: methodology, formal analysis and supervision; VCJ: investigation and resources; JESP: investigation and methodology; JSF: investigation and methodology. All authors critically reviewed the manuscript and approved the final version.

\section{(c) $\mathrm{BY}$}

